\title{
SOIL QUALITY UNDER AGROFORESTRY SYSTEMS AND TRADITIONAL AGRICULTURE IN THE ATLANTIC FOREST BIOME ${ }^{1}$
}

\author{
PATRICIA DIAS TAVARES ${ }^{2}$, CRISTIANE FIGUEIRA DA SILVA ${ }^{3}$, MARCOS GERVASIO PEREIRA $^{3 *}$, VANESSA \\ APARECIDA FREO ${ }^{3}$, WANDERLEI BIELUCZYK ${ }^{4}$, ELIANE MARIA RIBEIRO DA SILVA ${ }^{5}$
}

\begin{abstract}
In the present study, we evaluated the influence of agroforestry systems and traditional agriculture on the physical attributes and biologicals of soil, using as reference a native forest area in Paraty, RJ. Levels of total soil organic carbon, as well as oxidizable fractions and aggregate stability, were analyzed, in addition to the activity and carbon and nitrogen content in the soil microbial biomass, in the $0-5 \mathrm{~cm}$ layer, in two distinct seasons (dry and rainy seasons). The agroforestry systems and traditional agriculture maintain high levels of total organic carbon and its storage in more stable fractions. These systems provide the same conditions as those of the forest area for the aggregation of the soil. The microbial biomass was more responsive to variations in management and seasonality. The deployment of agroforestry systems contributes to the formation of a more diversified agricultural matrix, promoting improvements in the soil quality and connection with the remaining adjacent forest.
\end{abstract}

Keywords: Local knowledge. Soil aggregation. Soil microbial biomass. Soil organic carbon.

\section{QUALIDADE DO SOLO SOB SISTEMAS AGROFLORESTAIS E AGRICULTURA TRADICIONAL NO BIOMA FLORESTA ATLÂNTICA}

RESUMO - Esse estudo avaliou a influência dos sistemas agroflorestais e da agricultura tradicional sobre os atributos físicos e biológicos do solo, utilizando como referência uma área de floresta nativa em Paraty, RJ. Foram analisados os teores do carbono orgânico total do solo e suas frações oxidáveis, a estabilidade dos agregados, além da atividade e os teores de carbono e nitrogênio da biomassa microbiana do solo, na camada de $0-5 \mathrm{~cm}$, em duas épocas (seca e chuvosa) distintas. Os sistemas agroflorestais e a agricultura tradicional mantêm níveis elevados de carbono orgânico total e seu armazenamento em frações mais estáveis. Quando comparados à área de Floresta, esses sistemas proporcionam as mesmas condições para a agregação do solo. A biomassa microbiana foi mais responsiva as variações de manejo e sazonalidade. A implantação de sistemas agroflorestais contribui para a formação de uma matriz agrícola mais diversificada, promovendo melhorias na qualidade do solo e conexão com os remanescentes florestais próximos.

Palavras-chave: Conhecimento local. Agregação do solo. Biomassa microbiana do solo. Carbono orgânico do solo.

\footnotetext{
${ }^{*}$ Corresponding author

${ }^{1}$ Received for publication in 03/08/2017; accepted in 04/19/2018.

Paper extracted from the Masters dissertation of the first author.

${ }^{2}$ Instituto Federal de Educação, Ciência e Tecnologia de Brasília, Campus Planaltina, Planaltina, Brasília, DF, Brazil; patricia_floresta@yahoo.com.br-ORCID: 0000-0003-1970-2654.

${ }^{3}$ Department of Soils/Institute of Agronomy, Universidade Federal Rural do Rio de Janeiro, Seropédica, RJ, Brazil; cfigueirasilva@yahoo.com.br - ORCID: 0000-0003-4606-3149, gervasio@ufrrj.br - ORCID: 0000-0002-1402-3612, vafreo@gmail.com ORCID: 0000-0002-9428-0984.

${ }^{4}$ Nutrient Cycling Laboratory/Nuclear Energy Center in Agriculture, Universidade de São Paulo, Piracicaba, SP, Brazil; wanderleibieluczyk@gmail.com - ORCID: 0000-0003-0438-4673.

${ }^{5}$ Mycorrhizae Laboratory, Embrapa Agrobiologia, Seropédica, RJ, Brasil; eliane.silva@embrapa.br - ORCID: 0000-0002-9180-9870.
}

Rev. Caatinga, Mossoró, v. 31, n. 4, p. 954 - 962, out. - dez., 2018 


\section{INTRODUCTION}

The remnants of the Atlantic Forest, for the most part, are immersed in agricultural matrices, some of them in the form of conservation units. In the Costa Verde region of the state of Rio de Janeiro $(\mathrm{RJ})$, the creation of conservation units has created conflicts with native populations, due to the restrictions for the maintenance of agricultural and extractive activities. To minimize such conflicts and assist agricultural production, within and around these units, the use of agroforestry systems (AS) was encouraged, which are recognized by promoting biodiversity and environmental services through incorporation of forest components in livestock systems (FAO, 2013).

The implementation of AS associated with traditional agriculture (based on rotation, consortium of cultures, and fallow) among areas of forest remnants, mark the profile of many of agroecosystems of the region of Paraty - RJ (SOUZA; PIÑA-RODRIGUES, 2013; SILVA et al., 2012). With the deployment of AS, the agricultural matrix tends to become more diversified, offering shelter for animals and promoting connectivity between areas of forest remnants (PERFECTO; VANDERMEER 2010). This style of agriculture has the potential to support one of the emergencies of this century, i.e., to reconcile production of food with the conservation of natural resources (PERFECTO; VANDERMEER, 2010; SOUZA et al., 2012; FAO, 2013).

In addition to increasing biodiversity, AS can contribute to the promotion and maintenance of soil quality. The presence of trees in agricultural systems assists in the control of erosion and provides continuous input of organic matter to the soil (SILVA et al., 2012). In tropical agroecosystems, soil quality depends largely on plant biomass (JANDL et al. 2014) and permanence of litter, which provide protection for the soil and substrates for edaphic bodies, aiding in improvements in soil aggregation, water retention, and nutrient cycling (KIBBLEWHITE; RITZ; SWIFT, 2008).

The processing of organic matter and nutrient cycling are influenced by the biological activity of the soil. In this way the microbial biomass (BMS), defined as the living part of soil organic matter, is important for these processes (AQUINO; ASSIS, 2005). It corresponds to a small fraction of the total soil organic carbon and constitutes a part of the mineralizable soil potentially available to plants. Therefore, studies have used BMS as an indicator to characterize the influence of different management systems on soil quality (PEZARICO et al. 2013; KASCHUK; ALBERTON; HUNGRIA, 2011).

The hypothesis of the present study was therefore that the agroforestry systems contribute to the maintenance of soil attributes similar to the areas of forest remnants. Thus, the objective was to evaluate the effects of agroforestry systems and traditional agriculture on physical attributes and organic soil, comparing them with an area of native forest (forest) in the municipality of Paraty, RJ.

\section{MATERIAL AND METHODS}

\section{The study area}

The study was conducted in the quilombo of Campinho of Independence, located in the central part of the Environmental Protection Area of Cairuçu, in the district of Paraty-Mirim, municipality of Paraty (RJ) $\left(23^{\circ} 18^{\prime} 27^{\prime \prime S}\right.$ and $\left.44^{\circ} 42^{\prime} 32^{\prime \prime}\right)$, at an altitude of $60 \mathrm{~m}$ above sea level. The climate of the region is Cwa type according to the classification of Köppen, the average annual rainfall is $2.384 \mathrm{~mm}$, and average annual temperature is $27{ }^{\circ} \mathrm{C}$. The original vegetation of the study area is of type Submontane Ombrophylus Dense. The precipitation for the driest months (April/September) in the year 2012 was $360 \mathrm{~mm}$ and in the hottest months of (October/ March) 2012/13 was $476 \mathrm{~mm}$ (BRASIL, 2013).

\section{Description of the systems}

The study area has three agricultural systems, two agroforestry systems, and an area of traditional agriculture, which are located in the same position geographically, and next to a fragment of secondary forest (forest). The chemical attributes of the soil of the four areas are presented in Table 1.

Table 1. Chemical properties of the soil in the areas of forest, agroforestry systems (AS-1 and AS-2) and traditional agriculture (AT), at depths of $0-5 \mathrm{~cm}$, in the municipality of Paraty/RJ.

\begin{tabular}{|c|c|c|c|c|c|c|}
\hline \multirow{2}{*}{ Areas } & $\mathrm{pH}\left(\mathrm{H}_{2} \mathrm{O}\right)$ & $\mathrm{Ca}$ & $\mathrm{Mg}$ & $\overline{\mathrm{Al}}$ & $\mathrm{K}$ & \multirow{2}{*}{$\frac{\mathrm{P}}{\mathrm{mg} \mathrm{kg}^{-1} \text { soil }}$} \\
\hline & \multicolumn{5}{|c|}{ 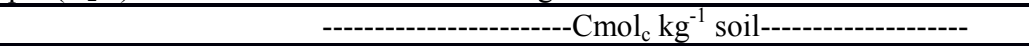 } & \\
\hline Forest & 4.69 & 3.89 & 2.55 & 0.59 & 0.18 & 4.27 \\
\hline AS-1 & 4.91 & 4.30 & 2.75 & 0.45 & 0.29 & 4.02 \\
\hline AS-2 & 5.32 & 2.90 & 2.08 & 0.16 & 0.13 & 3.68 \\
\hline $\mathrm{AT}$ & 5.16 & 3.27 & 2.02 & 0.09 & 0.39 & 4.00 \\
\hline
\end{tabular}

Agroforestry systems are implemented in a permanent preservation area on the banks of the Rio Carapitanga. In 2003, agroforestry systems were deployed as experimental units of regenerative agroforestry systems and similar, aiming at sustainable alternatives for the generation of income 
in traditional communities (SOUZA; PIÑARODRIGUES, 2013). The area occupied by agroforestry systems previously was used for production of the banana (Musa sp.) and cassava (Manihot esculenta). The AS were implanted in plots of $20 \times 20 \mathrm{~m}$, with single plantations (a seedling per hole) cultivating leguminous species (AS-1) and non -leguminous (AS-2). Currently, with the process of forest regeneration, these systems have different composition in relation to the moment of deployment (Table 2).

Table 2. Species raised in the year 2013 in agroforestry systems (AS-1 and AS-2) in the community of Campinho of Independence in the municipality of Paraty/RJ.

\begin{tabular}{lc}
\hline AS-1 & AS-2 \\
\hline
\end{tabular}

Ingá (Inga laurina); Embira de sapo (Lochocarpus huilleminianus (Tull.) Malme)
Ingá (Inga edulis e Inga laurina); Urucum (Bixa orelana L.); Embira de sapo (Lonchocarpus guilleminianus (Tull). Malme); Pau viola (Cytharexyllum myruanthum Cham)

Fruit trees species of long cycle

\begin{tabular}{|c|c|}
\hline $\begin{array}{l}\text { Abiu (Pouteria macrophylla Radkl.); Jaca (Artocarpus } \\
\text { heterophyllus Lam.); Carambola (Averrhoa carambola } \\
\text { L.); Goiaba (Psidium guajava); Graviola (Annona } \\
\text { muricata) }\end{array}$ & $\begin{array}{l}\text { Abiu ( Pouteria macrophylla } \text { Radkl.); Limão (Citrus sp.); Jaca } \\
\text { (Artocarpus heterophyllus Lam.); Carambola (Averrhoa } \\
\text { carambola L.); Goiaba (Psidium guajava); Graviola (Annona } \\
\text { muricata) }\end{array}$ \\
\hline \multicolumn{2}{|c|}{ Species of potential use of seeds, oils and hardwoods. } \\
\hline $\begin{array}{l}\text { Guapuruvu (Schizolobium parahyba (vell) Blake); Araribá } \\
\text { (Centrolobium tomentosum Guill. Ex Benth.); Jatobá } \\
\text { (Hymenaea courbaril L.); Copaíba (Copaiba langsdorfii } \\
\text { Desf) }\end{array}$ & $\begin{array}{l}\text { Cedro (Cedrela odorata); Canela (Nectranda lanceolata Ness } \\
\text { et Mart. ex Nees); Jequitibá (Cariniana legalis (Mart.) } \\
\text { Kuntze); Bicuiba (Virola bicuhyba (Schott) Warb.); }\end{array}$ \\
\hline \multicolumn{2}{|c|}{ Species from natural regeneration } \\
\hline \multirow[t]{5}{*}{ Terminalia sp. } & Clidemia urceolata \\
\hline & Embira de sapo (Lochocarpus huilleminianus (Tull.) Malme) \\
\hline & Miconia calvescens \\
\hline & Piptadenia paniculata \\
\hline & Schinus terebinthifolius \\
\hline \multicolumn{2}{|c|}{ The species that have entered the system after deployment } \\
\hline Jussara (Euterpe edulis Mart.) & Paineira (Ceiba speciosa) \\
\hline- & Jussara (Euterpe edulis Mart.) \\
\hline
\end{tabular}

The area of traditional agriculture (AT) is characterized by traditional management for the production of food (maize, beans, yam, banana), based in the consortium, crop rotation, and fallow. These are small areas of approximately $800 \mathrm{~m}^{2}$ and are normally cultivated next to forests.

\section{Sampling and analysis of soil}

The samples of soil were collected in two seasons of the year (rainy and dry), in the months of September 2012 and March 2013. Samples were taken at a depth of $0-5 \mathrm{~cm}$, where three simple samples were collected randomly forming a composite sample, totaling four composite samples per area. Up to $24 \mathrm{~h}$ after samples were collected from the field, $50 \mathrm{~g}$ of each sample was removed for the quantification of $\mathrm{C}, \mathrm{N}$, and microbial biomass activity. The remaining material was air dried for analysis of soil organic carbon and its oxidizable fractions. For the analysis of aggregate stability, four undisturbed samples were collected in each area, totaling 16 samples, at a depth $0-5 \mathrm{~cm}$, through the opening of mini trenches.
The total soil organic carbon (TOC) was quantified by the oxidation of the organic matter track wet, by using a solution of potassium dichromate in acid medium, with an external source of heat (YEOMANS; BREMNER, 1988). The fractionation was done by degrees of oxidation according to Chan, Bowman and Oates (2001). Samples of $0.1 \mathrm{~g}$ of soil were added in containers of $250 \mathrm{~mL}$, adding $10 \mathrm{~mL} \mathrm{~K}_{2} \mathrm{Cr}_{2} \mathrm{O}_{7} 0.167 \mathrm{~mol} \mathrm{~L}^{-1}$ and quantities of $\mathrm{H}_{2} \mathrm{SO}_{4}$ were wrapped in Erlenmeyer flasks corresponding to the concentrations $3,6,9$, and $12 \mathrm{~mol} \mathrm{~L}^{-1}$. The oxidation was performed without an external source of heat and the titration of the extracts was done with a solution of $\mathrm{Fe}\left(\mathrm{NH}_{4}\right)_{2}$ $\left(\mathrm{SO}_{4}\right) 2.6 \mathrm{H}_{2} \mathrm{O} 0.5 \mathrm{~mol} \mathrm{~L}^{-1}$. The indicator used was the Phenanthroline, and four fractions of carbon were obtained, with decreasing degrees of oxidation (F1, F2, F3, and F4).

The aggregation of the soil was determined by the method of valuation of aggregates stable in water (YOODER, 1936). From the data of mass of aggregates, the weighted average diameter (WAD) and the geometric mean diameter (GMD) of aggregates were calculated as described by 
Donagema et al. (2011).

The quantification of microbial activity was made on the basis of soil basal respiration (SBR) and metabolic quotient of soil $\left(\mathrm{qCO}_{2}\right)$, as proposed by Jenkinson and Powlson (1976). The determination of (N-BMS) and (C-BMS) were performed using the fumigation-extraction method. Quantification of NBMS was performed according to the methods of Brookes et al. (1985), using the distillation of steamdraggin (Kjeldahl) followed by acid-base volumetry with sulfuric acid as a titrator. Quantification of CBMS was done using the method proposed by Vance, Brookes and Jenkinson (1987).

\section{Statistical Analysis}

The data were evaluated for homoscedasticity using the Cochran test and for normal distribution using the Lilliefors test. Afterwards, data were analyzed using analysis of variance and the Bonferroni $t$ test $(\hat{\mathrm{I}} \pm=0.05)$ through SISVAR program 4.6. The grouping analysis was performed using the Gower method, through the program PAST, with the following variables: TOC, oxidizable fractions (F1, F2, F3 and F4), C-BMS, N$\mathrm{BMS}, \mathrm{SBR}$ and $q \mathrm{CO}_{2}$.

\section{RESULTS AND DISCUSSION}

\section{Carbon and its oxidizable fractions}

At the two periods assessed (rainy and dry) the agroforestry systems (AS) had content of total organic carbon (TOC) lower or equivalent to those quantified in the areas of forest and agriculture traditional (AT), where the differences found represent fluctuations of $10 \mathrm{~g} \mathrm{~kg}^{-1}$ of TOC on average between the areas, for each season (Table 3). Seasonal variations were observed only in the areas of forest, in which an increase in AS-1 and a reduction in AS- 2 of the TOC content of dry season versus rainy season samples was verified (Table 3).

Table 3. Total Organic Carbon (TOC) of the soil and its oxidized fractions (F1, F2, F3 and F4) in the forest area, agroforestry systems (AS-1 and AS-2) and traditional agriculture (AT), at the depth of $0-5 \mathrm{~cm}$, in different periods of the year, dry (Dr) and rainy (Ra), in the municipality of Paraty - RJ.

\begin{tabular}{|c|c|c|c|c|c|c|}
\hline \multirow{3}{*}{ Areas } & \multicolumn{2}{|c|}{ TOC } & \multicolumn{2}{|c|}{ F1 } & \multicolumn{2}{|c|}{ F2 } \\
\hline & \multicolumn{6}{|c|}{ - - } \\
\hline & Dr & $\mathrm{Ra}$ & $\overline{\mathrm{Dr}}$ & $\mathrm{Ra}$ & Dr & $\mathrm{Ra}$ \\
\hline Forest & $37.49 \mathrm{~b}$ & $43.40 a^{*}$ & $1.82 \mathrm{a}$ & $1.16 \mathrm{a}$ & $1.26 \mathrm{a}$ & $2.10 \mathrm{a}^{*}$ \\
\hline AS-1 & $33.937 \mathrm{c}$ & $35.55 b$ & $1.47 \mathrm{a}$ & $1.15 \mathrm{a}$ & $1.09 \mathrm{a}$ & $1.72 b^{*}$ \\
\hline AS-2 & $37.49 \mathrm{~b}$ & $32.65 \mathrm{~b}$ & $1.78 \mathrm{a}$ & $0.95 b$ & $1.33 \mathrm{a}$ & $1.76 \mathrm{~b}$ \\
\hline AT & $45.81 \mathrm{a}$ & $34.84 b^{*}$ & $1.91 \mathrm{a}$ & $0.92 b^{*}$ & $1.77 \mathrm{a}$ & $1.32 \mathrm{c}$ \\
\hline $\mathrm{CV} \% 1$ & 5.25 & 4.79 & 5.10 & 5.11 & 14.13 & 5.94 \\
\hline $\mathrm{CV} \% 2$ & & & & & & \\
\hline \multirow{3}{*}{ Areas } & & & & & & \\
\hline & \multicolumn{6}{|c|}{ 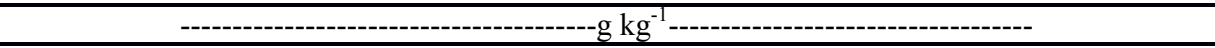 } \\
\hline & Dr & $\mathrm{Ra}$ & \multicolumn{2}{|c|}{ Dr } & \multicolumn{2}{|c|}{$\mathrm{Ra}$} \\
\hline Forest & $2.41 \mathrm{bc}$ & $3.41 \mathrm{a}^{*}$ & \multicolumn{2}{|c|}{$2.57 \mathrm{~b}$} & \multicolumn{2}{|c|}{$3.54 \mathrm{a}^{*}$} \\
\hline AS-1 & $1.98 \mathrm{c}$ & $3.07 \mathrm{ab} *$ & \multicolumn{2}{|c|}{$2.57 \mathrm{~b}$} & \multicolumn{2}{|c|}{$3.36 \mathrm{a}^{*}$} \\
\hline AS-2 & $2.50 \mathrm{ab}$ & $2.63 \mathrm{~b}$ & \multicolumn{2}{|c|}{$3.03 \mathrm{~b}$} & \multicolumn{2}{|c|}{$2.93 \mathrm{a}$} \\
\hline AT & $2.92 \mathrm{a}$ & $2.88 \mathrm{~b}$ & \multicolumn{2}{|c|}{$3.65 \mathrm{a}$} & \multicolumn{2}{|c|}{$3.20 \mathrm{a}$} \\
\hline $\mathrm{CV} \% 1$ & 24.28 & 6.88 & \multicolumn{2}{|c|}{25.48} & \multicolumn{2}{|c|}{7.92} \\
\hline $\mathrm{CV} \% 2$ & \multicolumn{2}{|c|}{69.01} & \multicolumn{4}{|c|}{77.18} \\
\hline
\end{tabular}

Values followed by equal lowercase letters in column do not differ statistically by Bonferroni $t$ test at $5 \%$ significance level.

*Indicates significant difference between seasons in the samples from each area according to Bonferroni's $\mathrm{T}$ test at $5 \%$.

The TOC content in all areas may be considered elevated for tropical regions. Thus, the traditional agricultural practices for the production of food (cassava, maize, yams, beans) based on fallow, consortium and crop rotation, associated with employing agroforestry for the cultivation of species of economic importance and conservation of biodiversity, has been shown to be efficient for the improvement and maintenance of TOC content. The maintenance of soil cover provides greater inputs of organic matter (ANDO et al., 2014), and low soil mobilization decreases the losses thereof, which is essential for the tropical regions, where the soil generally has low-activity clay, which is the most important organic matter fraction for the reduction of losses by leaching.

In relation to the carbon-oxidizable fractions, agroforestry systems (AS-1 and AS-2) associated with the forest, in general, have yielded higher contents of more labile fractions (F1 and F2), when compared to AT, with the exception of F1 fraction at AS-2 that do not differ significantly from AT (Table 3). With respect to the fractions of greater stability (F3 and F4), we found that, in the rainy 
season, the forest area had the highest contents of fraction F3, which were similar to AS-1. On the other hand, in the dry season, the AT area had the highest content of this fraction, while areas of AS-2 and forest showed intermediate values, and the smallest increment of $\mathrm{C}$ of fraction $\mathrm{F} 3$ was observed in the area of AS-1 (Table 3). Fraction F4 differed between the areas only in the dry season, with the highest $\mathrm{C}$ content quantified in the AT area (Table 3). For all fractions, in general, there was an increase in the concentrations of $\mathrm{C}$ from the dry season to the rainy season (Table 3 ).

Different forms of management can promote oxidation of $\mathrm{C}$ of soil under natural vegetation conditions when subjected to cultivation (MIELNICZUK et al., 2003). The stocks of $\mathrm{C}$ are determined by the balance of inputs, such as the inflow of the vegetable waste and the application of organic compounds, and the outputs, through decomposition of organic matter of the soil (MIELNICZUK et al., 2003). Soon, this process will be mediated by the management of agroecosystems, which may facilitate the storage of carbon. The observed patterns suggest that $\mathrm{C}$ is being stored in more stable fractions in the soil in the areas studied (AT, AS-1 and AS-2). The storage of carbon in the fractions of greater stability might be due to the efficiency in the processes of transformation of organic matter, mediated by micro-organisms that compose the microbial biomass, as well as other bodies that inhabit the soil. Thus, carbon could remain in the system longer.

\section{Soil aggregation}

For both the dry season and the rainy season, no significant differences were observed between the values of weighted average diameter (WAD) between areas, which averaged around $4.0 \mathrm{~mm}$. In addition, more than $96 \%$ of the aggregate of all areas were in the diameter above $2.0 \mathrm{~mm}$ (Table 4). The geometric mean diameter (GMD), in the rainy season, did not differ significantly between areas, whereas for the dry season, in the forest area, a lower diameter value was observed in comparison to that of the other areas.

Table 4. Weighted average diameter (WAD) and geometric average diameter (GMD) in forest area, agroforestry systems (AS-1 AND AS-2), and traditional agriculture (AT), at the depth of 0-5 cm, in different periods of the year, dry (Dr) and rainy $(\mathrm{Ra})$, in the municipality of Paraty - RJ.

\begin{tabular}{|c|c|c|c|c|}
\hline \multirow{3}{*}{ Areas } & \multicolumn{2}{|c|}{ WAD } & \multicolumn{2}{|c|}{ GMD } \\
\hline & \multicolumn{4}{|c|}{ 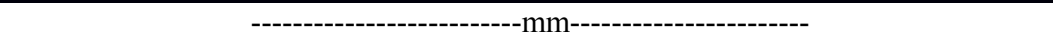 } \\
\hline & Dr & $\mathrm{Ra}$ & Dr & $\mathrm{Ra}$ \\
\hline Forest & $4.76 \mathrm{a}$ & $4.80 \mathrm{a}^{*}$ & $4.04 \mathrm{~b}$ & $4.62 \mathrm{a}$ \\
\hline AS-1 & $4.89 \mathrm{a}$ & $4.81 \mathrm{a}$ & $4.62 \mathrm{a}$ & $4.44 \mathrm{a}$ \\
\hline AS-2 & $4.89 \mathrm{a}$ & $4.89 \mathrm{a}$ & $4.62 \mathrm{a}$ & $4.51 \mathrm{a}$ \\
\hline AT & $4.88 \mathrm{a}$ & $4.89 \mathrm{a}$ & $4.59 \mathrm{a}$ & $4.68 \mathrm{a}$ \\
\hline $\mathrm{CV}(1) \%$ & 1.28 & 1.52 & 4.83 & 3.74 \\
\hline $\mathrm{CV}(2) \%$ & \multicolumn{2}{|c|}{1.47} & \multicolumn{2}{|c|}{5.10} \\
\hline
\end{tabular}

Values followed by equal letters in column do not differ statistically by Bonferroni t test at $5 \%$ significance level. CV (1)\% - Coefficient of variation between areas. $\mathrm{CV}(2) \%$ - coefficient of variation between seasons.

*Indicates significant difference between seasons in the samples from each area according to Bonferroni's $\mathrm{T}$ test at $5 \%$.

The areas of AS-1, AS-2, and AT provided similar conditions for the aggregation of the soil. This can be explained by the intense deposition of TOC in the soil, which is one of the main promoters of aggregation as observed in studies by Loss et al. (2009). Barreto et al. (2008) did not observe significant changes in the content of TOC of different systems evaluated (cocoa agroforestry, forest, and pasture), and attributed this result to management systems that preserve the soil organic matter, resulting in high levels of carbon. In addition, these authors suggested that the lowest soil provides greater preservation of macroaggregate, thus the TOC contents remain high. The conservation of TOC content, associated with the action of the organisms, can contribute to the maintenance of the aggregation indices (WAD and GMD) in these areas. Additionally, it should be highlighted that the high
TOC concentration in the most recalcitrant fractions helps to preserve carbon and increase the capacity of soil aggregation (LOSS et al., 2009).

\section{Nitrogen and Carbon of microbial biomass and microbial Indexes}

The content of microbial biomass carbon (C$\mathrm{BMS}$ ), in the rainy season, was greater in the forest area, differing from the areas of AS-1, AS-2 and TA (Table 5). In the dry season, the area of forest differed only from the area of AS-1, that presented the lowest concentrations of C-BMS. At that time, the AS-2 provided the largest values of C-BMS when compared to AT. The values of C-BMS and variations between the areas may be due to management practices, as well as the composition of the vegetation cover (LIU et al., 2012), which has a 
relationship with the quantity and quality of organic matter available and the activity of BMS (SIMÕES et al., 2010).

For the N-BMS, differences between areas in the dry season were not assessed. In the rainy season, higher average values in the AT area were observed. According to some authors (GAMA-RODRIGUES et al., 2005; SANTIAGO et al., 2013) there is an influence of rainfall on the concentration of N-BMS in soil. Thus, it is possible that the lower concentrations of N-BMS of soil in the dry season, for the areas AT and AS-1, are associated with reductions in the population and microbial activity.

Table 5. Carbon (C-BMS) and nitrogen (N-BMS) of microbial biomass, soil basal respiration (SBR) and metabolic quotient $\left(q \mathrm{CO}_{2}\right)$ in the forest area, agroforestry systems (AS-1 and AS-2) and traditional agriculture (AT), at the depth of $0-5 \mathrm{~cm}$, in different periods of the year, dry $(\mathrm{Dr})$ and rainy $(\mathrm{Ra})$, in the municipality of Paraty - RJ.

\begin{tabular}{|c|c|c|c|c|c|c|c|c|}
\hline \multirow{3}{*}{ Areas } & & $\mathrm{MS}$ & \multicolumn{2}{|c|}{ N-BMS } & \multicolumn{2}{|c|}{ SBR } & \multicolumn{2}{|c|}{$\mathrm{qCO}_{2}$} \\
\hline & \multicolumn{4}{|c|}{ - } & \multicolumn{2}{|c|}{ 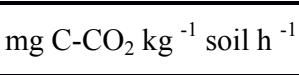 } & \multicolumn{2}{|c|}{$\begin{array}{c}\mathrm{mg} \mathrm{C}-\mathrm{CO}_{2} \cdot \mathrm{g}^{-1} \mathrm{BMS}-\mathrm{C} \\
\mathrm{h}^{-1}\end{array}$} \\
\hline & Dr & $\mathrm{Ra}$ & $\overline{\mathrm{Dr}}$ & $\mathrm{Ra}$ & Dr & $\mathrm{Ra}$ & $\mathrm{Dr}$ & $\mathrm{Ra}$ \\
\hline$\overline{S F}$ & $92.90 \mathrm{ab}$ & $708.18 a^{*}$ & $108.94 a$ & $366.51 b$ & $1.35 \mathrm{a}$ & $4.047 \mathrm{a}^{*}$ & $14.53 b$ & $5.77 \mathrm{a}$ \\
\hline AS-1 & $45.63 \mathrm{c}$ & $390.34 b *$ & $48.83 \mathrm{a}$ & $350.03 \mathrm{~b} *$ & $0.62 b$ & $2.72 \mathrm{ab} *$ & $13.95 b c$ & $7.31 \mathrm{a}$ \\
\hline AS-2 & $107.81 \mathrm{a}$ & $322.95 b$ & $86.38 \mathrm{a}$ & $285.47 b$ & $1.15 \mathrm{ab}$ & $2.52 \mathrm{~b}$ & $8.89 \mathrm{c}$ & $8.24 \mathrm{a}$ \\
\hline $\mathrm{AT}$ & $63.88 \mathrm{bc}$ & $284.35 \mathrm{~b}$ & $89.91 \mathrm{a}$ & $518.32 \mathrm{a} *$ & $1.54 \mathrm{a}$ & $2.98 \mathrm{ab}$ & $24.19 \mathrm{a}$ & $11.31 \mathrm{a}^{*}$ \\
\hline $\mathrm{CV} \%$ & 20.63 & 22.82 & 30.33 & 9.85 & 20.23 & 20.16 & 15.18 & 33.68 \\
\hline $\mathrm{CV} \%$ & & & & 34 & & 73 & & \\
\hline
\end{tabular}

Medium followed by the same lowercase letter in column and capitalize on the line does not differ by Bonferroni t test at $5 \%$ significance level.

*Indicates significant difference between seasons in the samples from each area according to Bonferroni's $\mathrm{T}$ test at $5 \%$.

Relative to soil basal respiration (SBR), in both seasons, the forest area had the highest values, however, this area significantly differed only from the area of AS-2, in the rainy season, and AS-1 in the dry season. Significant differences were found only between the AS area and the AT area in the dry season, where the AT area had greater rates of SBR. The SBR represents the release rate of $\mathrm{CO}_{2}$. Thus, the results observed in this study may indicate increased activity of BMS in the areas of the AT and forest, in the rainy and dry seasons, and at AS- 1 in the rainy season. This may be related to the accelerated process of decomposition of MOS and/or to the greater availability of MOS technology in the areas of the AT, forest, and AS-1 (SIMÕES et al., 2010).

In relation to seasonal variation, the AS-1 and the forest area showed the highest levels of C-BMS and SBR in the rainy season, while the AS-2 and the AT area did not show differences between seasons. For the N-BMS, significant differences were observed only in the AT area and at AS-1, where the rainy season had the highest average values. The variation of the macroclimatic conditions has an effect on activity and soil microbial biomass, which explains the seasonal fluctuations (WHITE; GOSZ, 1987). Variations like these were also observed by other authors (GAMA-RODRIGUES et al., 2005; SANTIAGO et al., 2013) in which an increase in rainfall led to an increase in the levels of N-BMS and C-BMS. The greatest immobilization of $\mathrm{C}$ and $\mathrm{N}$ by the BMS caused by rainfall can result in higher decomposition rates of MOS (GAMA-RODRIGUES et al., 2005).

The values of $\mathrm{qCO}_{2}$ differed between areas only in the dry season, since the greater average was associated with AT and the lowest mean was associated with AS-2. The values of $\mathrm{qCO}_{2}$ have a close relationship with the release rate of $\mathrm{CO}_{2}$. Higher values of this index reflect greater carbon losses, and the values indicate how each system interacts with the carbon stock, as a source or drain, in relation to soil (MELLONI; PERREIRA; ALVARENGA, 2008). The AS-2 area had higher CBMS and lower $\mathrm{qCO}_{2}$, in the dry season, which may indicate that this area would be acting as a carbon source to the ground, in that period. The area of the AT had the lowest levels of C-BMS and largest of $\mathrm{qCO}_{2}$ in this period, would act as a carbon drain for the soil.

\section{Multivariate Analysis}

The cluster analysis, integrating all the analyzed variables, showed that the pattern of similarity between the areas varied according to the season (dry and rainy seasons) of sampling (Figure $1 \mathrm{a}$ and $1 \mathrm{~b}$ ). However, the similarity between the areas of forest and the agroecosystems was around $50 \%$ for both periods (Figure 1a and $1 \mathrm{~b}$ ). In the dry season, the AS-2 was the system that most resembled the forest area (approximately 65\% similarity) (Figure 1a). While in the rainy season, the three agroecosystems showed similarity of $46 \%$ in comparison with the area of forest (Figure 1b). 

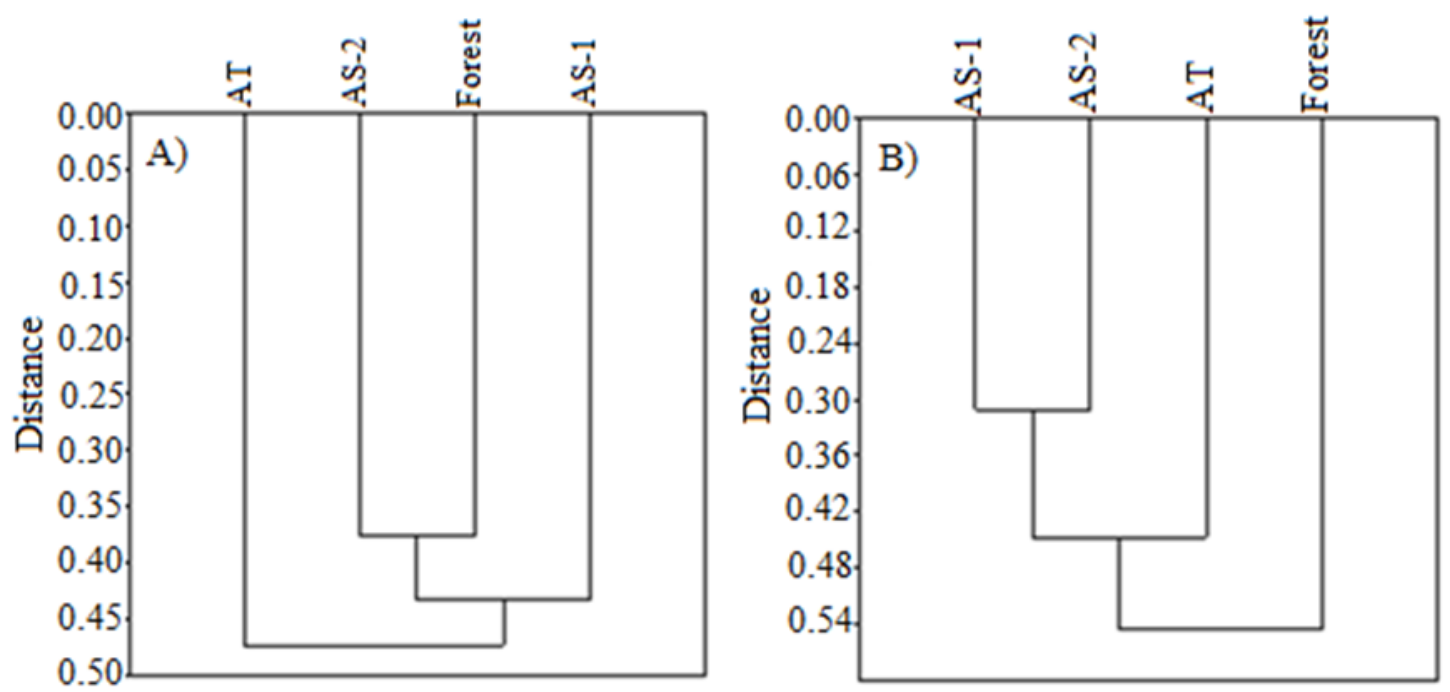

Figure 1. Cluster analysis using the method of Gower for chemical and microbiological variables of the soil of areas of forest, agroforestry systems (AS-1 and AS-2), and traditional agriculture (AT) for the two seasons of the year, dry (A) and rainy $(B)$ of the year in the municipality of Paraty, RJ.

The constitution of the agroecosystem formed by areas of AS and AT associated with forest ecosystems contributes to maintaining soil quality similar to that of the forest area. The AS and the forest areas surround the area of TA; it was therefore inferred that these arboreal structures and more biodiverse areas are protecting the agriculture area.

The combination of productive systems with different degrees of intensity, as to the use of the soil in agricultural landscapes, have been studied by several authors (JACKSON et al., 2012; FREITAS et al., 2013). The interactions provided by this combination are countless and some authors affirm that they contribute to making agroecosystems more sustainable (JACKSON et al., 2012; SOUZA et al., 2012). Among these interactions, the relationship with pollinators, the interactions of biological control of pests and diseases, as well as improvements in the soil quality were highlighted (JACKSON et al., 2012; SOUZA et al., 2012).

\section{CONCLUSIONS}

The management adopted in the areas of agroforestry systems (AS-1 and AS-2) and traditional agriculture (AT), in addition to maintaining high levels of total organic carbon also stores TOC in more stable fractions. The agricultural systems managed (AS-1, AS-2 and AT) on the basis of the indices of aggregation provided the same conditions for the aggregation of soil compared to the forest. The microbial biomass C-BMS and NBMS) was more responsive to variation in management and seasonality, sometimes having more elevated values in the agroecosystems as compared to the forest area. The formation of biodiverse agroecosystems contributes to the maintenance of the quality of the soil.

\section{ACKNOWLEDGEMENTS}

The authors acknowledge the Maroons Community of Campinho of Independence by receiving the proposal of the research and to the Graduate Program in Agronomy - Soil Science for the opportunity to develop the study and for financial support.

\section{REFERENCES}

ANDO, K. et al. Effects of cropping and shortnatural fallow rotation on soil organic carbon in the Eastern Province of Zambia. Agriculture, Ecosystems and Environmental, Bern, v. 196, s/n., p. 34-41, 2014.

AQUINO, A. M.; ASSIS, R. L. Processos biológicos no sistema solo-planta: ferramentas para uma agricultura sustentável. 1. ed. Brasília, DF: EMBRAPA, 2005. 368 p.

BARRETO, A. C et al. Fracionamento químico e físico do carbono orgânico total em um solo de mata submetido a diferentes usos. Revista Brasileira de Ciência do Solo, Viçosa, v. 32, n. 4, p. 471-78, 2008.

BRASIL. Instituto Nacional de Meteorologia. Clima. Disponível em:. <http://www.inmet.gov.br/ portal/> Acesso em: 10 nov. 2013.

BROOKES, P. C. et al. Chloroform fumigation and 
the release of soil nitrogen: a rapid direct extraction method to measure microbial biomass nitrogen in soil. Soil Biology and Biochemistry, Nottingham, v. 17, n. 6, p. 837-842, 1985.

CHAN, K. Y.; BOWMAN, A.; OATES, A. Oxidizidable organic carbon fractions and soil quality changes in an oxic paleustalf under different pasture ley. Soil Science, New Brunswick, v. 166, n. 4, p. 61-67, 2001.

DONAGEMA, G. K. et al. Manual de métodos de análise de solo. 2. ed. Rio de Janeiro, RJ: EMBRAPA SOLOS, 2011. 230 p.

FOOD AND AGRICULTURE ORGANIZATION OF THE UNITED NATIONS - FAO. Advancing Agroforestry on the Policy Agenda Food and Agriculture Organization of the United Nations. Food and Agriculture Organization of the United Nation Rome. Rome: Italy; 2013.

FREITAS, E C. S. et al. Deposição de serapilheira e de nutrientes no solo em sistema agrossilvipastoril com eucalipto e acácia. Revista Árvore, Viçosa, v. 37 , n. 3, p. 409-417, 2013

GAMA-RODRIGUES, E. F. et al. Nitrogênio, carbono e atividade da biomassa microbiana do solo em plantações de eucalipto. Revista Brasileira de Ciência do Solo, Viçosa, v. 29, n. 6, p. 893-901, 2005.

JACKSON, L. E. et al. Social-ecological and regional adaptation of agrobiodiversity management across a global set of research regions. Global Environmental Change, Netherlands, v. 22, n. 3, p. 623-639, 2012.

JANDL, R. et al. Current status, uncertainty and future needs in soil organic carbon monitoring. Science of the Total Environment, Barcelona, v. 468-469, s/n., p. 376-383, 2014.

JENKINSON, D. S.; POWLSON, D. S. The effects of biocidal treatments on metabolism in soil. V. A method for measuring soil biomass. Soil Biology and Biochemistry, Nottingham, v. 8, n. 3, p. 209213, 1976.

KASCHUK, G.; ALBERTON, O.; HUNGRIA, M. Quantifying effects of diferente agricultural land uses on soil microbial biomass and activity in Brazilian biomes: inferences to improve soil quality. Plant and Soil, Crawley, v. 338, n. 1, p. 467-481, 2011.

KIBBLEWHITE, M. G.; RITZ, K.; SWIFT, M. J. Soil health in agricultural systems: Philosophical Transactions of the Royal Society. Biological
Sciences, London, v. 363, n. 363, p. 685-670, 2008.

LIU, Y. et al. The long-term effects of reforestation on soil microbial biomass carbon in sub-tropic severe red soil degradation areas. Forest Ecololgy and Management, Sydney, v. 285, s/n., p. 77-84, 2012.

LOSS, A. et al. Atributos químicos e físicos de um Argissolo Vermelho-Amarelo em sistema integrado de produção agroecológica. Pesquisa Agropecuária Brasileira, Brasília, v. 44, n. 1, p. 68-75, 2009.

MELLONI, R.; PERREIRA, E. G. M.; ALVARENGA, M. I. N. Indicadores da qualidade do solo. Informe Agropecuário, Belo Horizonte, v. 29, n. 244, p. 17-29, 2008.

MIELNICZUK, J. et al. Manejo de solo e culturas e sua relação com os estoques de carbono e nitrogênio do solo. In: CURI, N. et al. (Eds). Tópicos em ciência do solo. Viçosa: Sociedade Brasileira de Ciência do Solo, 2003. v. 3. cap. 5, p. 209-248.

PERFECTO, A. I.; VANDERMEER, J. The agroecological matrix as alternative to the landsparing/agriculture intensification model. Proceedings of the National Academy of Sciences, Washington, v. 107, n. 13, p. 5786-5791, 2010.

PEZARICO, C. R. et al. Indicadores de qualidade do solo em Sistemas Agroflorestais. Revista de Ciências Agrárias, Belém, v. 56, n. 1, p. 40-47, 2013.

SANTIAGO, W. R. et al. Nitrogênio mineral e microbiano do solo em sistemas agroflorestais com palma de óleo na Amazônia oriental. Acta Amazônica, Manaus, v. 43, n. 4, p. 395-406, 2013.

SIMÕES, S. M. O. et al. Carbono orgânico e biomassa microbiana do solo em plantios de Acacia mangium no Cerrado de Roraima. Acta Amazônica, Manaus, v. 40, n.1, p. 23-30, 2010.

SILVA, M. S. C. et al. Estoque de Serapilheira e Atividade Microbiana em Solo sob Sistemas Agroflorestais. Floresta e Ambiente, Seropédica, v. 19, n. 4, p. 431-441, 2012

SOUZA, M. C. S.; PIÑA-RODRIGUES, F. C. M. Desenvolvimento de espécies arbóreas em sistemas agroflorestais para recuperação de áreas degradadas na floresta ombrófila densa, Paraty, RJ. Revista Árvore, Viçosa, v. 37, n.1, p. 89-98, 2013.

SOUZA, H. N. et al. Protective shade, tree diversity and soil properties in coffee agroforestry systems in the Atlantic Rainforest biome. Agriculture Ecosystems and Environmental, Bern, v. 146, n. 1, 
p. 179-196, 2012.

VANCE, E. D.; BROOKES, P.; JENKINSON, D. S. An extraction method for measuring soil microbial biomass-C. Soil Biology and Biochemistry, Nottingham, v. 19, n. 6, p. 703-707, 1987.

WHITE, C. S.; GOSZ, J. R. Factors controlling nitrogen mineralization and nitrification in forest ecosystems in New Mexico. Biological and Fertility of Soils, Firenze, v. 5, n. 3, p. 195-202, 1987.

YEOMANS, J. C.; BREMNER, J. M. A rapid and precise method for routine determination of organic carbon in soil. Communications in Soil Science and Plant Analysis, Georgia, v. 19, n. 13, p. 14671476, 1988.

YOODER, R. E. A direct method of aggregate analysis of soils and a study of the physical nature of erosion losses. American Society of Agronomy, Wisconsin, v. 28, n. 5, p. 337-251, 1936. 